\title{
Effects of the Extract Yam Powder Addition on Yogurt Properties during Storage
}

\author{
Sun-Young Lee, Joungjwa Ahn ${ }^{1}$, and Hae-Soo Kwak* \\ Department of Food Science and Technology, Sejong University, Seoul 143-747, Korea \\ ${ }^{1}$ Department of Herb Industry, Jungwon University, Goesan 367-805, Korea
}

\begin{abstract}
Physicochemical and sensory properties of Dioscorea opposita Thunb. (yam) powder-added yogurts (1, 3, 5, and 7\%, w/ v) were examined when stored at $4^{\circ} \mathrm{C}$ for $16 \mathrm{~d}$. When the yam concentration increased, the $\mathrm{pH}$ increased with $16 \mathrm{~d}$ storage. The lactic acid bacteria counts in all yogurt samples showed an increase during storage period, and the highest counts were appeared with $7 \%$ yam powder addition. The dramatic decrease was found in viscosity with higher concentrations of yam powder-added yogurt samples. No change was found in allantoin and diosgenin contents for $16 \mathrm{~d}$ storage periods. A significantly strong bitterness and astringency and decreased viscosity were found with 5 and $7 \%$ yam powder addition. However, less than 3\% yam powder-added yogurt samples did not show a significant difference compared with the control $(p>0.05)$ and overall acceptability score was the highest in $3 \%$ yam powder-added yogurt throughout the storage. The present study indicated that the concentrations ( 1 and $3 \%$, w/v) of yam powder could be used to produce yam powder-added yogurt without significant adverse effects on physicochemical, microbial and sensory properties, and enhance functional components from the supplementation.
\end{abstract}

Key words: yam powder, yogurt, allantoin, diosgenin

\section{Introduction}

Yogurt has gained widespread consumer acceptance throughout the world including Korea. It is well known that intestinal microflora patterns affect human health (Famularo et al., 2005; Kelly et al., 2005). Beneficial flora, such as the genera of Bifidobacterium or Lactobacillus, could inhibit the growth of pathogenic bacteria and decrease the level of carcinogenic materials, which further improves the colonic environment (Hsu et al., 2006; Rinne et al., 2005). Yogurt is rich in probiotics, such as lactic acid bacteria known to have health benefits, include enhanced intestinal microbial balance and food digestibility (Kim et al., 2005; Yoo et al., 2005). To increase the demand for yogurt, health beneficial yogurt should be focused and developed. In recent years, many different food ingredients, including $\beta$-glucan (Sahan et al., 2008), green and black teas (Jaziri et al., 2009) and chitosan (Seo et al., 2009) have been fortified to increase the

*Corresponding author: Hae-Soo Kwak, Department of Food Science and Technology, Sejong University, Seoul 143-747, Korea. Tel: 82-2-3408-3226, Fax: 82-2-3408-4319, E-mail: kwakhs (a)sejong.ac.kr yogurt formulations to improve the nutritional value. Under the technological point of view, the addition of yam powder may have positive action for the texture, stability or the consistency of the yogurt due to the availability of functional ingredients such as allantoin and diasgonin. Yam, the tuber part of the genus Dioscorea, has been used for many years as a traditional medicine (Shin et al., 2006) for the treatment of anorexia, chronic diarrhea, diabetes and excessive leucorrhea (Pharmacopoeia of the People's Republic of China, 1997). Health benefits of yam mainly rely on the allantoin and diosgenin content. Allantoin has a broad range of clinical acceptance (Yamamoto and Ogihara, 1998). It has long been known to enhance the efficacy and desirability of cosmetic creams and lotions through its action as a skin protectant. It also protects tissues in the stomach, accelerates the healing processes throughout the stomach and bowels, and promotes increased tissue repair throughout the entire gastrointestinal tract. Some researcher studied that lactic acid fermented yam doesn't have much effect on the functional components of yam.

Although yam (Dioscorea) has been revealed for various health benefits compared with other genus, little information of its application and research has been shown. 
To exploit the better health benefit for consumers, the development of a new functional yogurt using yam powder may be an alternative. Therefore, the objectives of the present study were to investigate the physicochemical and sensory changes of the yogurt added by yam powder during storage.

\section{Materials and Methods}

\section{Materials}

Tubers of Dioscorea opposita Thunb. (yam) were obtained from Research Center of Dongyang Industry (Korea) and were skinned, cut to $0.5-\mathrm{cm}$ thick slices, lyophilized, milled, and then passed through a 100-mesh sieve. The Dioscorea opposita Thunb powder were stored at $4^{\circ} \mathrm{C}$ until use. Raw milk (3.6\% milk fat) was purchased from Seoul Dairy Co-op (Korea). All chemicals were purchased from Sigma Chemical Co. (USA), and all solvents were of chromatographic grade.

\section{Preparation of Dioscorea opposita Thunb. Powder}

To prepare the Dioscorea opposita Thunb. (yam) powder, tubers of yam was washed, minced and spray-dried. Then two times of distilled water were added into the spray-dried yam sample and heated to $95^{\circ} \mathrm{C}$ for $120 \mathrm{~min}$ to discard the viscous mucilage. After centrifugation, the supernatant was transferred and added with Non-GMO dextrin powder $(\mathrm{DE}=8)$ and centrifuged again. Then, the supernatant was filtered and spray-dried.

\section{Manufacture of yam-added yogurt}

Milk containing $3.6 \%$ fat and $13.4 \%$ total solids was mixed with different amounts of yam powder $(1,3,5$, and $7 \%)$ and $3.7 \%(\mathrm{w} / \mathrm{v})$ skim milk powder and blended with Lab-blender (MS3040, MTops Misung, Korea) at 400 rpm for $5 \mathrm{~min}$. Each batch was made with $10 \mathrm{~L}$ of milk (2 $\mathrm{L}$ per treatment) at lab-scale level and the milk with completely solubilized yam powder was pasteurized at $90^{\circ} \mathrm{C}$ for $10 \mathrm{~min}$ in water bath. After cooling to $40^{\circ} \mathrm{C}, 0.02 \%$ commercial starter culture (Chr. Hansen, Pty. Ltd, Austrailia) in freeze-dried direct-to-vat set form containing Lactobacillus bulgaricus, Streptococcus thermophilus, and Bifidobacterium bifidum was added and fermented at $43^{\circ} \mathrm{C}$ for $6 \mathrm{~h}$ approximately the $\mathrm{pH}$ reaches 4.5 . After fermentation, all yogurt samples were removed and stored at $4^{\circ} \mathrm{C}$ for $16 \mathrm{~d}$ and the change in physicochemical, microbial and sensory properties during prolonged fermentation of yogurt were studied at 4-d intervals.

\section{pH and titratable acidity (TA)}

$\mathrm{pH}$ of the samples were measured at room temperature using $\mathrm{pH}$ meter (Orion 900A, USA). The TA was determined after mixing the $9 \mathrm{~mL}$ of yogurt sample with same amount of distilled water and titrating with $0.1 \mathrm{~N} \mathrm{NaOH}$ using a $0.5 \%$ phenolphthalein indicator to an end point of faint pink color. All samples were measured in triplicate.

\section{Microbial analysis}

MRS plate count agar (Difco Laboratories, USA) was used for lactic acid bacteria. One milliliter of sample diluted with $9 \mathrm{~mL}$ of sterile peptone and water diluent. Subsequent dilutions of each sample were plated in triplicate and incubated at $37^{\circ} \mathrm{C}$ for $48 \mathrm{~h}$.

\section{Viscosity}

Samples $(100 \mathrm{~mL})$ were placed in a Brookfield viscometer (spindle No. 2, Model LVDV I+, Version 3.0, USA) and measured from 5 to $8 \mathrm{~min}$ with $1 \mathrm{~min}$ period with 60 rpm. All samples were measured in triplicate.

\section{Color analysis}

Color values were compared between the control and the sample using a Hunter colorimeter (Minolta CT-310, Japan) after calibrating its original value with a standard plate. Measured $L^{*}, a^{*}$, and $b^{*}$ values were used as indicators of lightness, redness and yellowness, respectively. All samples were measured ten times.

\section{Allantoin and diosgenin analyses}

Ten milliliters of yogurt sample were removed periodically, extracted with $95 \%$ ethanol (v/v) for $30 \mathrm{~min}$ sonication at $4^{\circ} \mathrm{C}$ and evaporated in temperature-controlled waterbath. Then, $4 \mathrm{~mL}$ of distilled water was added, and the solution was resonicated for $30 \mathrm{~min}$ at $4^{\circ} \mathrm{C}$ and centrifuged at 7,700 g for $15 \mathrm{~min}$. The supernatant was decanted and filtered through a $0.45 \mu \mathrm{m}$ nylon syringe filter (Whatman International Ltd., England) and then injected for analysis.

Allantoin and diosgenin were quantitatively analyzed by Agilent 1200 Series HPLC system with Agilent 1200 Series diode-array detector (Agilent technology, Santa Clara, CA, USA) and Waters SunFire ${ }^{\mathrm{TM}} \mathrm{C}_{18} 5 \mu \mathrm{m}$ (4.6 $\mathrm{mm} \times 250 \mathrm{~mm}$ ) column (Milford, MA), with isocratic elution buffer. The conditions were as follow: For allantoin, mobile phase: $\mathrm{CH}_{3} \mathrm{CH}_{2} \mathrm{OH} / \mathrm{CHCl}_{3} / \mathrm{H}_{2} \mathrm{O}(0.5 / 0.012 / 100)$; flow rate: $0.2 \mathrm{~mL} / \mathrm{min}$ for 1 to $5 \mathrm{~min}$, increasing to 0.5 $\mathrm{mL} / \mathrm{min}$ after 5 to $15 \mathrm{~min}$ and to $0.2 \mathrm{~mL} / \mathrm{min}$ after 15 to 20 min; UV wavelength: $215 \mathrm{~nm}$; Injection volume: $20 \mu \mathrm{L}$. 
For diosgenin, mobile phase: $\mathrm{CH}_{3} \mathrm{CHOHCH}_{3} / \mathrm{CH}_{3} \mathrm{CN} /$ $\mathrm{H}_{2} \mathrm{O}(60 / 30 / 10)$; flow rate: $0.7 \mathrm{~mL} / \mathrm{min}$; UV wavelength: $213 \mathrm{~nm}$; Injection volume: $20 \mu \mathrm{L}$. The allantoin and diosgenin were quantified using the respective external standards. A standard graph for each was prepared by plotting concentration versus area. Quantification was carried out from integrated peak areas of the sample and corresponding standard graph.

\section{Sensory analysis}

For the sensory test, $10 \mathrm{~mL}$ yogurt sample was stored at $4^{\circ} \mathrm{C}$ for $0,4,8,12$ and $16 \mathrm{~d}$. Twelve-trained panelists then evaluated randomly coded yogurts in Dairy Products Lab, Food Science and Technology Department, Sejong University, Seoul, Korea with the age of 25-33 years and were familiar with yogurt consumption. The intensities of yogurt appearance, flavor, taste and texture were evaluated on a seven-point scale $(1=$ extremely weak, $4=$ moderate and $7=$ extremely strong). Overall acceptability was also scored on a seven-point scale ( $1=$ dislike extremely, $4=$ neither like nor dislike and $7=$ like extremely). A randomized, balanced, complete block design was used (Cochran and Cox 1957) that resulted in two replications for all samples.

\section{Statistical analysis}

All statistical analyses were performed using SAS version 9.0 (SAS Institute Inc., USA). An ANOVA was performed using the general linear models procedure to determine significant differences among the samples. Means were compared by using Fisher's least significant difference procedure. Significance was defined at the 5\% level.

\section{Results and Discussion}

\section{pH and titratable acidity (TA)}

Figs. 1 and 2 shows the changes in $\mathrm{pH}$ and TA values of the yogurt sample added with various concentrations of yam powder at $4^{\circ} \mathrm{C}$ for $16 \mathrm{~d}$ storage. $\mathrm{pH}$ were about 4.46 for the control and 4.42-4.46 for the yogurt samples with yam powder of different concentrations $(1,3,5$, and $7 \%$, w/v) (Fig. 1), which is considered to be acceptable range of the commercial yogurt. All the samples showed same trend, which showed the slight decrease up to $8 \mathrm{~d}$ and sharp decrease thereafter up to $16 \mathrm{~d}$. The yogurt samples added with 5 and $7 \%$ yam powder showed the dramatic decrease after $8 \mathrm{~d}$ storage compared to others. Shin et al. (2006) observed that fermentation of Dioscorea

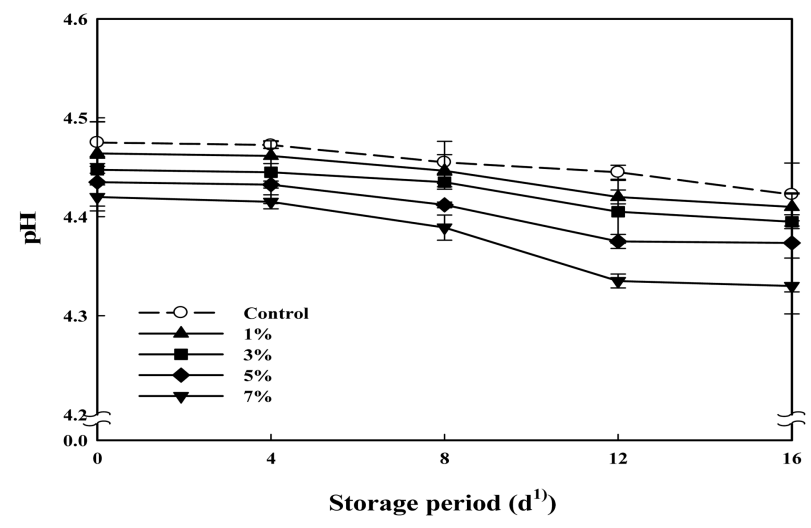

Fig. 1. Changes of $\mathrm{pH}$ in Dioscorea opposita Thunb. powderadded yogurt stored at $4^{\circ} \mathrm{C}$ for $16 \mathrm{~d} .{ }^{1)} 0 \mathrm{~d}$ means the sample obtained after $24 \mathrm{~h}$ from yogurt making.

batatas Decne solution by the combination culture of $L$. acidophilus, $S$. thermophilus and B. bifidus resulted in lower $\mathrm{pH}$ 4.33. After $16 \mathrm{~d}$ storage, all the samples including the control existed in the range of 4.34 and 4.46, which is considered to be the acceptable range of the commercial yogurt.

Fig. 2 shows the changes of TA (\%) values of the yogurt samples with various concentrations of Dioscorea opposita Thunb. powder for $16 \mathrm{~h}$ storage. The higher concentration of yam powder added, the higher TA values were shown and TA increased at the beginning of the storage $(0 \mathrm{~d})$. Even though a significant difference was found between the control and samples, similar trend was observed and the values were acceptable as a commercial yogurt throughout the storage. Samples added with 5 and $7 \%$ yam powder showed the significant increase after $4 \mathrm{~d}$ storage $(p<0.05)$ compared with other samples. These

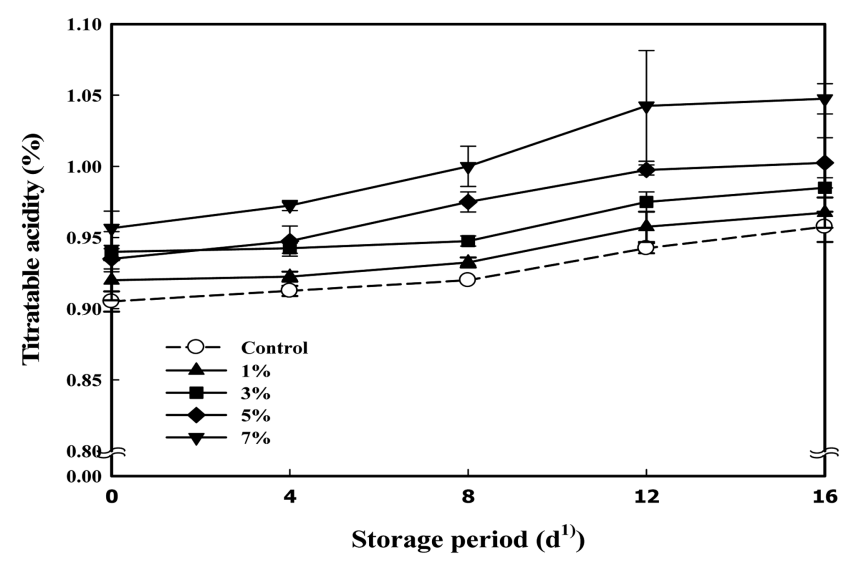

Fig. 2. Changes of titratable acidity in Dioscorea opposita Thunb. powder-added yogurt stored at $4^{\circ} \mathrm{C}$ for $16 \mathrm{~d}$. ${ }^{1)} 0 \mathrm{~d}$ means the sample obtained after $24 \mathrm{~h}$ from yogurt making. 


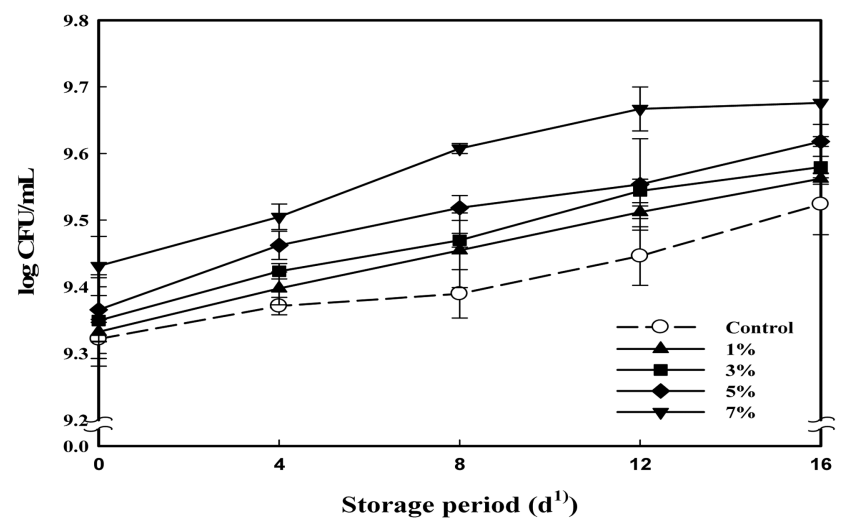

Fig. 3. Changes of lactic acid bacteria in Dioscorea opposita Thunb. powder-added yogurt stored at $4^{\circ} \mathrm{C}$ for $16 \mathrm{~d}$. ${ }^{1)} 0 \mathrm{~d}$ means the sample obtained after $24 \mathrm{~h}$ from yogurt making.

results indicated that 1 and 3\% yam powder addition did not provide any significant adverse effect on the yogurt $\mathrm{pH}$ and TA properties.

\section{Microbial counts of yogurt during storage}

The change of lactic acid bacteria counts in samples and control stored at $4^{\circ} \mathrm{C}$ for $16 \mathrm{~d}$ storage is presented in Fig. 3. At $0 \mathrm{~d}$, the mean counts of lactic acid bacteria were not significantly different between the control and the samples $(p>0.05)$ except for $7 \%$ added yogurt. Asiedu and Sanni (2002) reported that yam tuber rich in starch and mucilage which facilitate the growth of lactic acid bacteria. Increasing the concentration of yam powder in yogurt provides high amount of starch and mucilage which favors the counts of lactic acid bacteria from 9.32 to $9.65 \log \mathrm{CFU} / \mathrm{mL}$ as the storage time increased to $16 \mathrm{~d}$. Lactic acid bacteria can also produce enzymes which could hydrolyze starch into reducing sugars (Abodjo Kakou et al., 2010) which can further metabolized into lactic acids (Abodjo Kakou et al., 2010; Coulin et al., 2006). It was also confirmed by increase in TA values of yogurt supplemented with yam powder during increase storage time of $16 \mathrm{~d}$ (Fig. 1).

The present study was in accordance with other studies. In study by Cho et al. (2003), the lactic acid bacteria counts increased during fermentation when 0.5 to $6 \%$ of Lycii fructus, Lycii folium, and Lycii cortex were added,. Also, Shin et al. (2006) reported that fermentation of Chinese yam increased various lactic acid bacteria counts with increasing concentration of yam powder. The present data indicated that yam powder addition showed a profound effect on the growth of lactic acid bacteria.

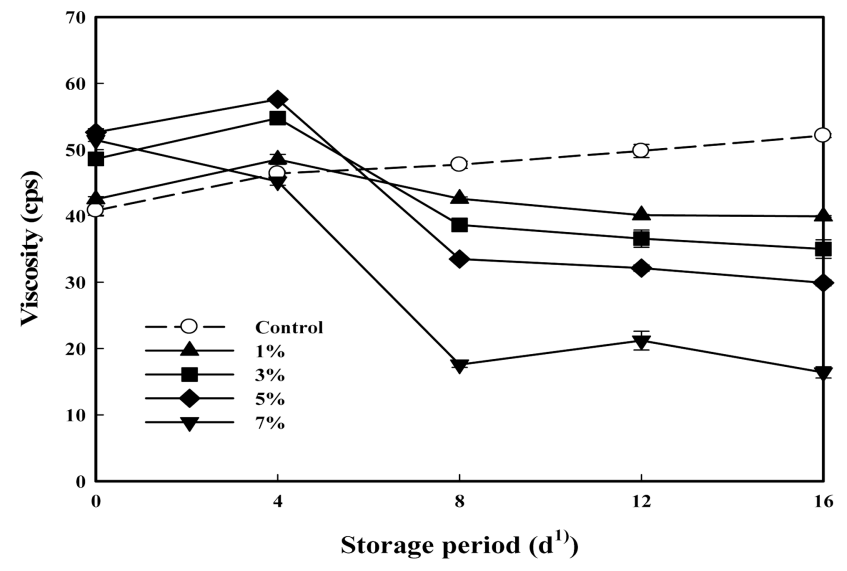

Fig. 4. Changes of viscosity in Dioscorea opposita Thunb. powder-added yogurt stored at $4^{\circ} \mathrm{C}$ for $16 \mathrm{~d} .{ }^{1)} 0 \mathrm{~d}$ means the sample obtained after $24 \mathrm{~h}$ from yogurt making.

\section{Viscosity}

Fig. 4 shows the change of viscosity of all the samples stored at $4^{\circ} \mathrm{C}$ for $16 \mathrm{~d}$. At early stage of storage, a significantly high viscosity was found in 3, 5 and $7 \%$ Dioscorea opposita Thunb. powder-added samples compared to the control $(p<0.05)$. The control yogurt showed the steadyincreasing with storage. However, the dramatic decrease was observed after $4 \mathrm{~d}$ storage in all yam powder containing samples. Tthe degree of decrease got higher as the amount added greater. At $16 \mathrm{~d}$, the viscosity in the control was 52.1 , whereas $39.9,35.0$, and $29.9 \mathrm{cps}$ in the 1,3 and $5 \%$ added samples, respectively.

Viscosity development is related to the aggregation of casein micelles and gel formation consequently to the biochemical and physicochemical changes during fermentation of milk (Dalgleish and Law 1988). Yam mucilage contains soluble proteins, such as mannose binding lectin and dioscorin, which also enhance the viscosity (Myoda et al., 2006). At 0 and $4 \mathrm{~d}$ storage, the viscosity value increased with increased concentration of yam powder added yogurt. However, the addition of extracted yam powder at higher level (7\%) did not show increasing viscosity in yogurt at various storage times (Fig. 4). Antonov et al. (1996) postulated that casein in yogurt interacts with starch lead to increase in viscosity, but promoting phase separation (Amaya-Liano et al., 2008; Williams et al., 2004). Thus addition of higher concentration of yam powder in yogurt may enhance the phase separation with lower viscosity during the storage.

In addition, Kim et al. (2010) has reported that raw yam powder addition to the yogurt increased the viscosity. The reason of the decreased viscosity with the yam powder addition in this study could be attributed to the 
Table 1. Changes of color in Dioscorea opposita Thunb. powder-added yogurt stored at $4^{\circ} \mathrm{C}$ for $16 \mathrm{~d}^{1)}$

\begin{tabular}{ccccccc}
\hline \hline \multirow{2}{*}{ Color } & $\begin{array}{c}\text { Conc. } \\
(\%)\end{array}$ & \multicolumn{5}{c}{ Storage period (d) } \\
\cline { 2 - 7 } & 0 & $85.96 \pm 0.30^{\mathrm{cA}}$ & $86.75 \pm 0.67^{\mathrm{abA}}$ & $86.34 \pm 0.34^{\mathrm{bcA}}$ & $86.85 \pm 0.65^{\mathrm{abA}}$ & $87.11 \pm 1.02^{\mathrm{aA}}$ \\
& 1 & $84.33 \pm 0.75^{\mathrm{cB}}$ & $86.42 \pm 0.43^{\mathrm{bA}}$ & $85.32 \pm 0.53^{\mathrm{cB}}$ & $86.50 \pm 0.86^{\mathrm{bA}}$ & $87.41 \pm 0.17^{\mathrm{aA}}$ \\
L $^{*}-$ & 3 & $84.36 \pm 0.42^{\mathrm{cC}}$ & $85.63 \pm 0.25^{\mathrm{bB}}$ & $83.58 \pm 0.51^{\mathrm{dC}}$ & $84.60 \pm 0.38^{\mathrm{cB}}$ & $86.27 \pm 0.42^{\mathrm{aB}}$ \\
(lightness) & 5 & $82.45 \pm 0.54^{\mathrm{dD}}$ & $84.08 \pm 0.29^{\mathrm{bC}}$ & $82.34 \pm .48^{\mathrm{dD}}$ & $88.07 \pm 0.25^{\mathrm{cC}}$ & $85.18 \pm 0.21^{\mathrm{aC}}$ \\
& 7 & $83.43 \pm 0.27^{\mathrm{cE}}$ & $82.68 \pm 1.08^{\mathrm{bD}}$ & $81.06 \pm 0.41^{\mathrm{cE}}$ & $80.99 \pm 0.30^{\mathrm{cD}}$ & $83.97 \pm 0.32^{\mathrm{aD}}$ \\
\hline & 0 & $2.25 \pm 0.13^{\mathrm{cA}}$ & $1.99 \pm 0.24^{\mathrm{bA}}$ & $2.26 \pm 0.09^{\mathrm{cA}}$ & $2.40 \pm 0.24^{\mathrm{cA}}$ & $2.19 \pm 0.30^{\mathrm{aA}}$ \\
& 1 & $2.28 \pm 0.23^{\mathrm{bA}}$ & $1.96 \pm 0.12^{\mathrm{cA}}$ & $2.40 \pm 0.24^{\mathrm{aA}}$ & $2.46 \pm 0.09^{\mathrm{aA}}$ & $2.15 \pm 0.07^{\mathrm{bAB}}$ \\
a*- $^{*}$ & 3 & $1.91 \pm 0.12^{\mathrm{cB}}$ & $1.85 \pm 0.11^{\mathrm{cAB}}$ & $2.03 \pm 0.12^{\mathrm{bB}}$ & $2.09 \pm 0.12^{\mathrm{abB}}$ & $2.16 \pm 0.10^{\mathrm{aA}}$ \\
& 5 & $1.70 \pm 0.22^{\mathrm{bC}}$ & $1.70 \pm 0.09^{\mathrm{bC}}$ & $1.73 \pm 0.23^{\mathrm{bC}}$ & $1.86 \pm 0.14^{\mathrm{abC}}$ & $1.98 \pm 0.14^{\mathrm{aBC}}$ \\
& 7 & $1.77 \pm 0.09^{\mathrm{bD}}$ & $1.77 \pm 0.06^{\mathrm{bBC}}$ & $1.49 \pm 0.15^{\mathrm{cD}}$ & $1.66 \pm 0.11^{\mathrm{bD}}$ & $1.96 \pm 0.14^{\mathrm{aC}}$ \\
\hline & 0 & $3.66 \pm 0.24^{\mathrm{abA}}$ & $2.99 \pm 0.61^{\mathrm{cC}}$ & $3.46 \pm 0.29^{\mathrm{abcA}}$ & $3.98 \pm 0.68^{\mathrm{aAB}}$ & $3.34 \pm 0.83^{\mathrm{bcB}}$ \\
$\mathrm{b}^{*}$ - & 1 & $3.64 \pm 0.50^{\mathrm{bcA}}$ & $3.11 \pm .47^{\mathrm{dBC}}$ & $3.34 \pm 0.56^{\mathrm{bcdA}}$ & $4.20 \pm 0.34^{\mathrm{aA}}$ & $3.82 \pm 0.18^{\mathrm{abB}}$ \\
& 3 & $3.62 \pm 0.34^{\mathrm{cA}}$ & $3.69 \pm 0.36^{\mathrm{bcA}}$ & $3.34 \pm 0.19^{\mathrm{cA}}$ & $4.03 \pm 0.41^{\mathrm{bAB}}$ & $4.50 \pm 0.37^{\mathrm{aA}}$ \\
& 5 & $3.24 \pm 0.57^{\mathrm{cA}}$ & $3.43 \pm 0.32^{\mathrm{bcAB}}$ & $3.30 \pm 0.42^{\mathrm{cA}}$ & $3.77 \pm 0.32^{\mathrm{bAB}}$ & $4.41 \pm 0.39^{\mathrm{aA}}$ \\
& 7 & $3.68 \pm 0.31^{\mathrm{bA}}$ & $3.66 \pm 0.24^{\mathrm{bA}}$ & $3.02 \pm 0.53^{\mathrm{cA}}$ & $3.60 \pm 0.25^{\mathrm{bA}}$ & $4.91 \pm 0.38^{\mathrm{aA}}$ \\
\hline
\end{tabular}

${ }^{1)}$ Values with different superscripts in a raw (a-d) and column (A-C) are significant at $\mathrm{p}<0.05$.

${ }^{2)} 0 \mathrm{~d}$ means the sample obtained after $24 \mathrm{~h}$ from yogurt making.

heating and other processes to remove the viscous materials in extraction process of yam powder. The present study indicated that there was a significant adverse defect in yogurt viscosity with Dioscorea opposita Thunb. (yam) powder, if the storage period prolonged to $4 \mathrm{~d}$ and longer.

\section{Color}

The changes in color for yogurt samples and control stored at $4^{\circ} \mathrm{C}$ for $16 \mathrm{~d}$ storage are presented in Table 1. The $L^{*}$ values for the yogurts-added with 3,5 , and $7 \%$ yam powder were significantly lower than those for the control in every storage period. The value of $\mathrm{a}^{*}$ value showed the similar trend to the $\mathrm{L}^{*}$ value. Shirai et al. (1992) observed that yogurt syneresis induced a decrease in $a^{*}$ values because the whey released by the yogurt contains riboflavin, which has a very important green component. On the other hand, yam powder added $(1 \%$, w/v)

Table 2. Changes of allantoin in Dioscorea opposita Thunb. powder-added yogurt stored at $4^{\circ} \mathrm{C}$ for $16 \mathrm{~d}^{1)}$

$(\mu \mathrm{g} / \mathrm{mL})$

\begin{tabular}{crrrrr}
\hline \hline \multirow{2}{*}{ Conc. (\%) } & \multicolumn{5}{c}{ Storage period (d) } \\
\cline { 2 - 6 } & \multicolumn{1}{c}{$0^{2)}$} & \multicolumn{1}{c}{8} & 12 & 16 \\
\hline 1 & $3.24 \pm 0.14^{\mathrm{a}}$ & $3.21 \pm 0.06^{\mathrm{a}}$ & $3.07 \pm 0.11^{\mathrm{a}}$ & $3.14 \pm 0.09^{\mathrm{a}}$ & $3.21 \pm 0.05^{\mathrm{a}}$ \\
3 & $5.08 \pm 0.11^{\mathrm{a}}$ & $4.39 \pm 0.14^{\mathrm{a}}$ & $4.89 \pm 0.08^{\mathrm{a}}$ & $5.05 \pm 0.15^{\mathrm{a}}$ & $5.06 \pm 0.14^{\mathrm{a}}$ \\
5 & $11.20 \pm 0.14^{\mathrm{a}}$ & $11.19 \pm 0.11^{\mathrm{a}}$ & $11.28 \pm 0.26^{\mathrm{a}}$ & $11.41 \pm 0.01^{\mathrm{a}}$ & $10.99 \pm 0.18^{\mathrm{a}}$ \\
7 & $15.06 \pm 0.26^{\mathrm{a}}$ & $15.01 \pm 0.14^{\mathrm{a}}$ & $15.02 \pm 0.15^{\mathrm{a}}$ & $14.83 \pm 0.17^{\mathrm{a}}$ & $14.81 \pm 0.06^{\mathrm{a}}$ \\
\hline
\end{tabular}

${ }^{1)}$ Values within the same row with different superscripts are significantly different at $p<0.05$.

${ }^{2)} 0 \mathrm{~d}$ means the sample obtained after $24 \mathrm{~h}$ from yogurt making.

Table 3. Changes of diosgenin in powdered extract of Dioscorea opposita Thunb. powder-added yogurt stored at $4^{\circ} \mathrm{C}$ for $16 \mathrm{~d}^{1)}$

$(\mu \mathrm{g} / \mathrm{mL})$

\begin{tabular}{cccccc}
\hline \hline \multirow{2}{*}{ Conc. (\%) } & \multicolumn{5}{c}{ Storage period (d) } \\
\cline { 2 - 6 } & $0^{2)}$ & 4 & 8 & 12 & 16 \\
\hline 1 & $13.36 \pm 0.27^{\mathrm{a} 2)}$ & $13.29 \pm 0.63^{\mathrm{a}}$ & $13.76 \pm 0.21^{\mathrm{a}}$ & $13.60 \pm 0.18^{\mathrm{a}}$ & $12.96 \pm 0.33^{\mathrm{a}}$ \\
3 & $39.73 \pm 1.77^{\mathrm{a}}$ & $40.04 \pm 0.19^{\mathrm{a}}$ & $40.41 \pm 0.11^{\mathrm{a}}$ & $40.67 \pm 0.50^{\mathrm{a}}$ & $39.62 \pm 1.42^{\mathrm{a}}$ \\
5 & $69.40 \pm 0.59^{\mathrm{a}}$ & $69.10 \pm 1.02^{\mathrm{a}}$ & $68.92 \pm 0.16^{\mathrm{a}}$ & $68.55 \pm 0.43^{\mathrm{a}}$ & $69.40 \pm 0.66^{\mathrm{a}}$ \\
7 & $94.77 \pm 1.13^{\mathrm{a}}$ & $95.93 \pm 1.18^{\mathrm{a}}$ & $94.57 \pm 0.48^{\mathrm{a}}$ & $94.57 \pm 0.63^{\mathrm{a}}$ & $94.18 \pm 0.90^{\mathrm{a}}$ \\
\hline
\end{tabular}

${ }^{1}$ Values within the same row with different superscripts are significantly different at $p<0.05$.

${ }^{2)} 0 \mathrm{~d}$ means the sample obtained after $24 \mathrm{~h}$ from yogurt making. 
yogurt showed the lowest syneresis at 8 and $12 \mathrm{~d}$ (Table 1) because of the high capacity of the yam powder to hold water. Thus, yam powder addition increases less whey-off from the yogurt and highest $\mathrm{a}^{*}$ values were obtained (less greenness). However, the $b^{*}$ values increased from 0 to $16 \mathrm{~d}$. The $\mathrm{b}^{*}$ values of yam powder added yogurt at all

Table 4. Sensory characteristics for Dioscorea opposita Thunb. powder-added yogurt stored at $4^{\circ} \mathrm{C}$ for $16 \mathrm{~d}^{1)}$

\begin{tabular}{|c|c|c|c|c|c|c|}
\hline \multirow{2}{*}{$\begin{array}{c}\text { Sensory } \\
\text { description }\end{array}$} & \multirow{2}{*}{ Conc. (\%) - } & \multicolumn{5}{|c|}{ Storage period (d) } \\
\hline & & $0^{2)}$ & 4 & 8 & 12 & 16 \\
\hline \multirow{5}{*}{ Whey-off } & 0 & $4.00 \pm 0.01^{\mathrm{aA}}$ & $4.00 \pm 0.01^{\mathrm{aA}}$ & $4.00 \pm 0.01^{\mathrm{aB}}$ & $4.00 \pm 0.01^{\mathrm{aB}}$ & $4.00 \pm 0.01^{\mathrm{aB}}$ \\
\hline & 1 & $4.00 \pm 0.01^{\mathrm{aA}}$ & $4.13 \pm 0.23^{\mathrm{aA}}$ & $4.00 \pm 0.01^{\mathrm{aB}}$ & $4.19 \pm 0.37^{\mathrm{aAB}}$ & $4.13 \pm 0.35^{\mathrm{aAB}}$ \\
\hline & 3 & $4.10 \pm 0.35^{\mathrm{aA}}$ & $4.44 \pm 0.82^{\mathrm{aA}}$ & $4.00 \pm 0.01^{\mathrm{aB}}$ & $4.19 \pm 0.37^{\mathrm{aAB}}$ & $4.13 \pm 0.35^{\mathrm{aAB}}$ \\
\hline & 5 & $4.10 \pm 0.35^{\mathrm{aA}}$ & $4.25 \pm 0.46^{\mathrm{aA}}$ & $4.13 \pm 0.35^{\mathrm{aAB}}$ & $4.00 \pm 0.01^{\mathrm{aB}}$ & $4.19 \pm 0.37^{\mathrm{aAB}}$ \\
\hline & 7 & $4.30 \pm 0.46^{\mathrm{aA}}$ & $4.06 \pm 0.18^{\mathrm{aA}}$ & $4.38 \pm 0.52^{\mathrm{aA}}$ & $4.50 \pm 0.76^{\mathrm{aA}}$ & $4.50 \pm 0.53^{\mathrm{aA}}$ \\
\hline \multirow{5}{*}{ White-color } & 0 & $4.00 \pm 0.01^{\mathrm{aAB}}$ & $4.00 \pm 0.01^{\mathrm{aA}}$ & $4.00 \pm 0.01^{\mathrm{aA}}$ & $4.00 \pm 0.01^{\mathrm{aA}}$ & $4.00 \pm 0.01^{\mathrm{aA}}$ \\
\hline & 1 & $4.13 \pm 0.35^{\mathrm{aA}}$ & $4.00 \pm 0.53^{\mathrm{aA}}$ & $4.00 \pm 0.01^{\mathrm{aA}}$ & $3.81 \pm 0.31^{\mathrm{aAB}}$ & $3.69 \pm 0.46^{\mathrm{aA}}$ \\
\hline & 3 & $3.88 \pm 0.35^{\mathrm{aAB}}$ & $3.88 \pm 0.35^{\mathrm{aA}}$ & $3.88 \pm 0.35^{\mathrm{aA}}$ & $3.88 \pm 0.23^{\mathrm{aA}}$ & $3.43 \pm 0.82^{\mathrm{aA}}$ \\
\hline & 5 & $3.75 \pm 0.46^{\mathrm{aAB}}$ & $3.38 \pm 0.44^{\mathrm{aAB}}$ & $3.25 \pm 0.46^{\mathrm{aB}}$ & $3.56 \pm 0.50^{\mathrm{aAB}}$ & $2.56 \pm 0.56^{\mathrm{bB}}$ \\
\hline & 7 & $3.56 \pm 0.73^{\mathrm{aB}}$ & $2.75 \pm 0.76^{\mathrm{abC}}$ & $2.75 \pm 0.53^{\mathrm{abC}}$ & $3.25 \pm 1.04^{\mathrm{aB}}$ & $2.06 \pm 0.68^{\mathrm{bC}}$ \\
\hline \multirow{5}{*}{ Herb } & 0 & $1.00 \pm 0.01^{\mathrm{aC}}$ & $1.00 \pm 0.01^{\mathrm{aC}}$ & $1.00 \pm 0.01^{\mathrm{aB}}$ & $1.00 \pm 0.01^{\mathrm{aC}}$ & $1.00 \pm 0.01^{\mathrm{aB}}$ \\
\hline & 1 & $1.25 \pm 0.46^{\mathrm{aBC}}$ & $1.38 \pm 0.46^{\mathrm{aBC}}$ & $1.13 \pm 0.35^{\mathrm{aB}}$ & $1.25 \pm 0.38^{\mathrm{aBC}}$ & $1.13 \pm 0.35^{\mathrm{aB}}$ \\
\hline & 3 & $1.44 \pm 0.50^{\mathrm{aBC}}$ & $1.44 \pm 0.42^{\mathrm{aBC}}$ & $1.31 \pm 0.46^{\mathrm{aB}}$ & $1.75 \pm 0.76^{\mathrm{aAB}}$ & $1.44 \pm 0.50^{\mathrm{aAB}}$ \\
\hline & 5 & $1.94 \pm 0.94^{\mathrm{aAB}}$ & $1.88 \pm 0.37^{\mathrm{aAB}}$ & $2.19 \pm 1.07^{\mathrm{aA}}$ & $1.81 \pm 0.84^{\mathrm{aAB}}$ & $1.81 \pm 0.84^{\mathrm{aA}}$ \\
\hline & 7 & $2.38 \pm 0.88^{\mathrm{aA}}$ & $2.06 \pm 0.65^{\mathrm{aA}}$ & $2.38 \pm 0.74^{\mathrm{aA}}$ & $2.13 \pm 0.83^{\mathrm{aA}}$ & $2.06 \pm 0.82^{\mathrm{aA}}$ \\
\hline \multirow{5}{*}{ Sourness } & 0 & $4.00 \pm 0.01^{\mathrm{aAB}}$ & $4.00 \pm 0.01^{\mathrm{aA}}$ & $4.00 \pm 0.01^{\mathrm{aA}}$ & $4.00 \pm 0.01^{\mathrm{aA}}$ & $4.00 \pm 0.01^{\mathrm{aA}}$ \\
\hline & 1 & $4.14 \pm 0.64^{\mathrm{aAB}}$ & $4.25 \pm 0.46^{\mathrm{aA}}$ & $4.13 \pm 0.23^{\mathrm{aA}}$ & $4.06 \pm 0.56^{\mathrm{aA}}$ & $4.44 \pm 0.50^{\mathrm{aA}}$ \\
\hline & 3 & $4.38 \pm 0.58^{\mathrm{aA}}$ & $3.94 \pm 0.42^{\mathrm{aA}}$ & $4.31 \pm 0.37^{\mathrm{aA}}$ & $4.31 \pm 0.70^{\mathrm{aA}}$ & $4.13 \pm 0.35^{\mathrm{aA}}$ \\
\hline & 5 & $4.25 \pm 0.71^{\mathrm{aAB}}$ & $4.19 \pm 0.37^{\mathrm{aA}}$ & $4.25 \pm 0.38^{\mathrm{aA}}$ & $4.13 \pm 0.58^{\mathrm{aA}}$ & $4.00 \pm 0.93^{\mathrm{aA}}$ \\
\hline & 7 & $3.75 \pm 0.46^{\mathrm{bB}}$ & $4.00 \pm 0.65^{\mathrm{abA}}$ & $4.38 \pm 0.52^{\mathrm{abA}}$ & $4.69 \pm 0.96^{\mathrm{aA}}$ & $4.25 \pm 0.89^{\mathrm{abA}}$ \\
\hline \multirow{5}{*}{ Bitterness } & 0 & $1.00 \pm 0.01^{\mathrm{aA}}$ & $1.00 \pm 0.01^{\mathrm{aB}}$ & $1.00 \pm 0.01^{\mathrm{aA}}$ & $1.00 \pm 0.01^{\mathrm{aB}}$ & $1.00 \pm 0.01^{\mathrm{aC}}$ \\
\hline & 1 & $1.00 \pm 0.01^{\mathrm{aA}}$ & $1.00 \pm 0.01^{\mathrm{aB}}$ & $1.06 \pm 0.18^{\mathrm{aA}}$ & $1.00 \pm 0.01^{\mathrm{aB}}$ & $1.06 \pm 0.18^{\mathrm{aBC}}$ \\
\hline & 3 & $1.06 \pm 0.18^{\mathrm{aA}}$ & $1.13 \pm 0.23^{\mathrm{aA}}$ & $1.19 \pm 0.37^{\mathrm{aA}}$ & $1.00 \pm 0.01^{\mathrm{aB}}$ & $1.19 \pm 0.37^{\mathrm{aBC}}$ \\
\hline & 5 & $1.06 \pm 0.18^{\mathrm{bA}}$ & $1.00 \pm 0.23^{\mathrm{bB}}$ & $1.19 \pm 0.37^{\mathrm{abA}}$ & $1.00 \pm 0.01^{\mathrm{bB}}$ & $1.44 \pm 0.50^{\mathrm{aAB}}$ \\
\hline & 7 & $1.13 \pm 0.35^{\mathrm{abA}}$ & $1.00 \pm 0.01^{\mathrm{bB}}$ & $1.38 \pm 0.52^{\mathrm{abA}}$ & $1.25 \pm 0.46^{\mathrm{abA}}$ & $1.50 \pm 0.46^{\mathrm{aA}}$ \\
\hline \multirow{5}{*}{ Astringency } & 0 & $1.00 \pm 0.01^{\mathrm{aA}}$ & $1.00 \pm 0.01^{\mathrm{aC}}$ & $1.00 \pm 0.01^{\mathrm{aB}}$ & $1.00 \pm 0.01^{\mathrm{aA}}$ & $1.00 \pm 0.01^{\mathrm{aB}}$ \\
\hline & 1 & $1.06 \pm 0.18^{\mathrm{bA}}$ & $1.13 \pm 0.23^{\mathrm{bC}}$ & $1.06 \pm 0.18^{\mathrm{bB}}$ & $1.00 \pm 0.01^{\mathrm{bA}}$ & $1.00 \pm 0.18^{\mathrm{aAB}}$ \\
\hline & 3 & $1.19 \pm 0.37^{\mathrm{aA}}$ & $1.38 \pm 0.52^{\mathrm{aBC}}$ & $1.19 \pm 0.26^{\mathrm{aAB}}$ & $1.13 \pm 0.35^{\mathrm{aA}}$ & $1.13 \pm 0.35^{\mathrm{aAB}}$ \\
\hline & 5 & $1.06 \pm 0.18^{\mathrm{bA}}$ & $1.38 \pm 0.52^{\mathrm{abAB}}$ & $1.44 \pm 0.50^{\mathrm{bAB}}$ & $1.06 \pm 0.18^{\mathrm{abA}}$ & $1.25 \pm 0.38^{\mathrm{aA}}$ \\
\hline & 7 & $1.19 \pm 0.37^{\mathrm{aA}}$ & $1.31 \pm 0.46^{\mathrm{bA}}$ & $1.69 \pm 0.46^{\mathrm{aA}}$ & $1.31 \pm 0.46^{\mathrm{aA}}$ & $1.38 \pm 0.58^{\mathrm{aAB}}$ \\
\hline \multirow{5}{*}{ Grainy } & 0 & $4.00 \pm 0.01^{\mathrm{aB}}$ & $4.00 \pm 0.01^{\mathrm{aB}}$ & $4.00 \pm 0.01^{\mathrm{aA}}$ & $4.00 \pm 0.01^{\mathrm{aAB}}$ & $4.00 \pm 0.01^{\mathrm{aA}}$ \\
\hline & 1 & $4.00 \pm 0.01^{\mathrm{aB}}$ & $4.00 \pm 0.01^{\mathrm{aB}}$ & $4.00 \pm 0.01^{\mathrm{aA}}$ & $4.13 \pm 0.35^{\mathrm{aA}}$ & $4.13 \pm 0.23^{\mathrm{aA}}$ \\
\hline & 3 & $4.13 \pm 0.35^{\mathrm{aAB}}$ & $4.06 \pm 0.18^{\mathrm{aB}}$ & $4.13 \pm 0.35^{\mathrm{aA}}$ & $4.13 \pm 0.23^{\mathrm{aA}}$ & $4.06 \pm 0.18^{\mathrm{aA}}$ \\
\hline & 5 & $4.00 \pm 0.01^{\mathrm{aB}}$ & $4.13 \pm 0.35^{\mathrm{aB}}$ & $4.13 \pm 0.35^{\mathrm{aA}}$ & $4.13 \pm 0.35^{\mathrm{aA}}$ & $4.00 \pm 0.01^{\mathrm{aA}}$ \\
\hline & 7 & $4.31 \pm 0.46^{\mathrm{abA}}$ & $4.44 \pm 0.50^{\mathrm{aA}}$ & $3.88 \pm 0.64^{\mathrm{bcA}}$ & $3.75 \pm 0.46^{\mathrm{cB}}$ & $4.00 \pm 0.01^{\mathrm{abcA}}$ \\
\hline \multirow{5}{*}{ Viscosity } & 0 & $4.00 \pm 0.01^{\mathrm{aAB}}$ & $4.00 \pm 0.01^{\mathrm{aBC}}$ & $4.00 \pm 0.01^{\mathrm{aA}}$ & $4.00 \pm 0.01^{\mathrm{aB}}$ & $4.00 \pm 0.01^{\mathrm{aA}}$ \\
\hline & 1 & $3.63 \pm 0.74^{\mathrm{aB}}$ & $3.56 \pm 0.50^{\mathrm{aC}}$ & $3.31 \pm 0.70^{\mathrm{aB}}$ & $3.13 \pm 0.58^{\mathrm{aC}}$ & $2.88 \pm 0.79^{\mathrm{aB}}$ \\
\hline & 3 & $4.81 \pm 1.51^{\mathrm{aA}}$ & $5.13 \pm 0.79^{\mathrm{aA}}$ & $4.13 \pm 0.58^{\mathrm{abA}}$ & $4.88 \pm 0.99^{\mathrm{aA}}$ & $3.75 \pm 0.71^{\mathrm{bA}}$ \\
\hline & 5 & $4.88 \pm 0.99^{\mathrm{aA}}$ & $4.31 \pm 0.53^{\mathrm{abB}}$ & $4.00 \pm 0.53^{\mathrm{bB}}$ & $4.13 \pm 0.44^{\mathrm{bB}}$ & $2.44 \pm 0.73^{\mathrm{cB}}$ \\
\hline & 7 & $3.25 \pm 0.46^{\mathrm{aB}}$ & $2.63 \pm 0.52^{\mathrm{bD}}$ & $2.38 \pm 0.52^{\mathrm{bC}}$ & $2.13 \pm 0.38^{\mathrm{bD}}$ & $1.50 \pm 0.53^{\mathrm{cC}}$ \\
\hline \multirow{5}{*}{$\begin{array}{l}\text { Overall accept- } \\
\text { ability }\end{array}$} & 0 & $4.00 \pm 0.01^{\mathrm{aA}}$ & $5.38 \pm 1.06^{\mathrm{aA}}$ & $5.38 \pm 0.74^{\mathrm{aA}}$ & $5.44 \pm 0.62^{\mathrm{aA}}$ & $5.38 \pm 0.74^{\mathrm{a} A \mathrm{~B}}$ \\
\hline & 1 & $4.13 \pm 0.23^{\mathrm{aA}}$ & $5.00 \pm 1.31^{\mathrm{aA}}$ & $5.25 \pm 1.16^{\mathrm{aA}}$ & $5.25 \pm 1.04^{\mathrm{aAB}}$ & $5.31 \pm 0.70^{\mathrm{aAB}}$ \\
\hline & 3 & $4.44 \pm 0.82^{\mathrm{abA}}$ & $4.81 \pm 1.31^{\mathrm{bA}}$ & $5.63 \pm 0.74^{\mathrm{abA}}$ & $5.88 \pm 1.13^{\mathrm{abA}}$ & $6.06 \pm 0.78^{\mathrm{aA}}$ \\
\hline & 5 & $4.25 \pm 0.46^{\mathrm{aA}}$ & $6.00 \pm 0.93^{\mathrm{aA}}$ & $5.81 \pm 0.92^{\mathrm{aA}}$ & $5.75 \pm 1.16^{\mathrm{aA}}$ & $5.13 \pm 0.99^{\mathrm{aB}}$ \\
\hline & 7 & $5.38 \pm 0.74^{\mathrm{abA}}$ & $5.31 \pm 0.70^{\mathrm{aA}}$ & $6.06 \pm 0.78^{\mathrm{abA}}$ & $5.13 \pm 0.99^{\mathrm{bB}}$ & $3.94 \pm 0.94^{\mathrm{bC}}$ \\
\hline
\end{tabular}

${ }^{1)}$ Values with different superscripts in a raw (a-d) and column (A-C) are significant at $p<0.05$.

${ }^{2)} 0 \mathrm{~d}$ means the sample obtained after $24 \mathrm{~h}$ from yogurt making. 
concentrations $(1,3,5$, and $7 \%, \mathrm{w} / \mathrm{v})$ were not considerably changed ( $p>0.05)$. According to Needs et al. (2000), yogurt $b^{*}$ values can be enhanced during storage at $4^{\circ} \mathrm{C}$. Higher concentration of yam powder (over $3 \%$ ) and refrigerated storage $\left(4^{\circ} \mathrm{C}\right)$ enhances higher $b^{*}$ value during storage time of $16 \mathrm{~d}$.

\section{Allantoin and diosgenin contents}

The changes of allantoin and diosgenin contents of yogurt added with different concentrations of yam powder and the control for $16 \mathrm{~d}$ storage are presented in Tables 2 and 3. As expected, both allantoin (Table 2) and diosgenin (Table 3 ) contents were higher in samples containing higher percentage of Dioscorea opposita Thunb. powder. The content of allantoin was 3.24 and diosgenin $13.36 \mu \mathrm{g} / \mathrm{mL}$ when $1 \%(\mathrm{w} / \mathrm{v})$ yam powder addition to the yogurt. Both components did not change quantitatively for $16 \mathrm{~d}$ storage. Some researcher reported that the contents of allantoin and diosgenin vary with the storage time, type of yam and extraction process in yam powder. In our preliminary study, the yam powder contains considerably low amount allantoin and diosgenin contents. This fact confirms that extraction process affects the content of both allantoin and diosgenin in the yam.

\section{Sensory evaluation}

The sensory attributes of the yogurt stored at $4^{\circ} \mathrm{C}$ for 16 $\mathrm{d}$ are shown in Table 4. The whey-off scores for the yam powder-added yogurt at various concentrations $(1,3,5$, and $7 \%, \mathrm{w} / \mathrm{v}$ ) and the control were not significantly influenced by prolonged storage ( $16 \mathrm{~d}$ ) or the addition of yam powder $(p>0.05)$. The white-color scores at $0 \mathrm{~d}$ and $16 \mathrm{~d}$ storage were significantly decreased $(p<0.05)$ when the greater concentration $(7 \%, \mathrm{w} / \mathrm{v})$ of yam powder-added yogurts, probably because of the original yellow color of the yam powder. This coincide with the higher $b^{*}$ value of yogurt addition with higher concentration $(7 \%, \mathrm{w} / \mathrm{v})$ of yam powder at 0 and $16 \mathrm{~d}$ storage (Table 1). The herb score for the yogurt sample added with yam powder at various concentrations were not significantly affected during $16 \mathrm{~d}$ storage $(p>0.05)$. In the taste test, it was revealed that adding yam powder $(7 \%, \mathrm{w} / \mathrm{v})$ into yogurt samples caused a significant decrease in the sourness scores $(p<0.05)$ and a slight increase in the astringency scores at $16 \mathrm{~d}$ storage $(p>0.05)$. The greater astringency scores for yogurt samples that include the higher concentration of yam powder $(3,5$, and $7 \%, \mathrm{w} / \mathrm{v})$ were probably the result of the astringent flavor of the yam powder. Seo et al. (2009) also observed that addition of chitosan in yogurt increase the astringent value of yogurt during $16 \mathrm{~d}$ storage. According to the texture test, the grainy scores for the yam powder added yogurt at $16 \mathrm{~d}$ storage were not significantly affected by the addition of yam powder $(p<0.05)$. Finally, adding yam powder into the yogurt samples did not significantly influence the overall acceptability at 0,4 and $8 \mathrm{~d}$ storage. Based on all the sensory data obtained from the current study, it is suggested that concentrations $(1-3 \%$, w/v) of yam powder could be used for the production of the yogurt without affecting the sensory properties.

From the present study, we may suggest that extracted powder from Dioscorea opposita Thunb. could be used as a novel ingredient in yogurt production. On the view point of health aspects, the yam powder added yogurt acts as a functional yogurt which can improve gut function by the supplement of allantoin and diosgenin without any modification during fermentation and storage of yogurt at $16 \mathrm{~d}$. The data on the $\mathrm{pH}, \mathrm{TA}$, viscosity, allantion, diosgenin, color, microbial and sensory analysis obtained from the current study indicated that concentrations $(1-3 \%, \mathrm{w} /$ v) of yam powder could be applicable in yogurt development. This broadens the application of yam powder in yogurt and opens the way for the development of other fermented foods for health benefits.

\section{References}

1. Abodjo Kakou, C., Tagro Guehi, S., Olo, K., Akissi Kouame, F., Koffi Nevry, R., and Marina Koussemon, C. (2010) Biochemical and microbial changes during traditional spontaneous lactic acid fermentation process using two varieties of cassava for production of a "Alladjan" starter. Int. Food Res. J. 17, 563-573.

2. Amaya-Llano, S. L., Martínez-Alegría, A. L., Zazueta-Morales, J. J., Martínez-Bustos, F. (2008) Acid thinned jicama and maize starches as fat substitute in stirred yogurt. LWT - Food Sci. Technol. 41, 1274-1281.

3. Antonov, Y. A., Lashko, N. P., Glotova, Y. K., Malovikova, A., and Markovich, O. (1996) Effect of the structural features of pectins and alginates on their thermodynamic compatibility with gelatine in aqueous media. Food Hydrocolloid 10, 1-9.

4. Asiedu, M., and Sanni, A. I. (2002) Chemical composition and microbiological changes during spontaneous and starter culture fermentation on Eman Ne-Setaakye, a West African fermented fish-carbohydrate product. Eur. Food Res. Technol. 215, 8-12.

5. Cho, J. R., Bae, H. C., and Nam, M. S. (2003) Fermentation properties of yogurt added by Lycii fructus, Lycii foiium and Lycii cortex. Kor. J. Food Sci. Ani. Resour. 23, 250-261.

6. Cochran, W. G., and Cox, G. M. (1957) Experimental designs. John Wiley \& Sons, New York, NY. 
7. Coulin, P., Farah, Z., Assanvo, J., Spillmann, H., and Puhan, Z. (2006) Characterisation of the microflora of attieke a fermented cassava product, during traditional small scale preparation. Int. J. Food Microbiol. 106, 131-136.

8. Dalgleish, D. G., and Law, A. J. R. (1988) pH-induced dissociation of bovine casein micelles. I. Analysis of liberated caseins. J. Dairy Res. 55,529-538.

9. Famularo, G., De Simone, C., Pandey, V., Sahu, A. R., and Minisola, G. (2005) Probiotic lactobaccilli: an innovative tool to correct the malabsorption syndrome of vegetarians? Med. Hypotheses 65, 1132-1135.

10. Hsu, C. C., Huang, Y. C., Yin, M. C., and Lin, S. J. (2006) Effect of yam (Dioscorea alata compared to Dioscorea japomica) on gastrointestinal function and antioxidant activity in mice. J. Food Sci. 71, 513-516.

11. Jaziri, I., Slama, M. B., Mhadhbi, H., Urdaci, M. C., and Hamdi, M. (2009) Effect of green and black teas (Camellia sinensis L.) on the characteristic microflora of yogurt during fermentation and refrigerated storage, Food Chem. 112, 614-620.

12. Kelly, D., Conway, S., and Aminow, R. (2005) Commensal gut bacteria: mechanisms of immune modulation. Trends Immunol. 26, 326-333.

13. Kim, K. M., Kim, K. H., Kim, S. Y., Park, Y. S., Seo, M. J., and Yoon, S. S. (2005) Isolation and characterization of antilisterial lactic acid bacteria from kimchi. Food Sci. Biotechnol. 14, 503-508.

14. Kim, S. H. (2010) Physicochemical properties of Dioscoreaopposita Thunb. fermented by lactic acid bacteria and its gastroprotective effect, and application into yogurt. Ph.D. thesis, Sejong Univ., Seoul, Korea.

15. Myoda, T., Matsuda, Y., Suzuki, T., Nakagawa, T., Nagai, T., and Nagashima, T. (2006) Identification of soluble proteins and interaction with mannan in mucilage of Dioscorea opposita Thunb. (Chinese yam tuber). Food Sci. Technol. Res. 12, 299-302.

16. Needs, E., Capellas, M., Bland, P., Manoj, P., McDougal, D., and Paul, G. (2000) Comparison of heat and pressure treatments of skim milk, fortified with whey protein concentrate, for set yogurt preparation: effects on milk proteins and gel structure. J. Dairy Res. 67, 329-348.

17. Pharmacopoeia Commission of the Chinese Ministry of Public Health (1997) Pharmacopoeia of the People's Republic of China, Vol. 1, Chemical Industry, China Meical Science and Technology, Press, China

18. Rinne, M., Kalliomaki, M., Arvilommi, H., Salminen, S., and Isolauri, E. (2005) Effects of ptobiotics and breastfeeding on the bifidobacterium and lactobacillus/enterococcus microbiota and humoral immune responses. J. Pediatr. 147, 186-191.

19. Sahan, N., Yasar, K., and Hayaloglu, A. A. (2008) Physical, chemical and flavour quality of non-fat yogurt as affected by a $\beta$-glucan hydrocolloidal composite during storage. Food Hydrocolloid 22, 1291-1297.

20. Seo, M. H., Lee, S. Y., Chang, Y. H., and Kwak, H. S. (2009) Physicochemical, microbial, and sensory properties of yogurt supplemented with nanopowdered chitosan during storage. J. Dairy Sci. 92, 5907-5916.

21. Shin, K. O., Jeon, J. R., Lee, J. S., Kim, J. Y., Lee, C. H., Kim, S. C., Yu, Y., and Nam, D. H. (2006) Lactic acid fermentation of Chinese Yam (Dioscorea batatas Decne) flour and its pharmaceutical effect on gastrointestinal function in rat model. Biotechol. Bioproc. E. 11, 240-244.

22. Shirai, K., Pedraza, G., Gutie'rrez-Dura'n, M., Marshall, V., Revah-Moiseev, S., and Garcý'a-Garibay, M. (1992) Production of a yogurt-like product from plant foodstuffs and whey. Substrate preparation and fermentation. J. Sci. Food Agric. 59, 199-204.

23. Williams, R. P. W., Glagovskaia, O., and Augustin, M. A. (2004) Properties of stirred yogurts with added starch: Effects of blends of skim milk powder and whey protein concentrate on yogurt texture. Aust. J. Dairy Technol. 59, 214220.

24. Yoo, E. J., Lim, H. S., Park, K. O., and Choi, M. R. (2005) Cytotoxic antioxidative, and ACE inhibiting activities of Dolsan leaf mustard juice (DLMJ) treated with lactic acid bacteria. Biotechnol. Bioproc. E. 10, 60-66.

(Received 2010.9.24/Revised 2011.2.7/Accepted 2011.2.10) 